\title{
Munnstell er en forsømt sykepleieoppgave
}

Eldre sykehjemsbeboere får ikke godt nok munnstell fordi sykepleiere kan synes det er ubehagelig, de har for dårlig tid, mangler kompetanse eller får motstand fra pasientene.

\section{Gunvor Svensli}

Sykepleier

Ørstaheimen, Ørsta kommune

Amanda Flåskjer

Sykepleier

Intensivavdelingen, Volda sjukehus, Helse Møre og Romsdal

Torill Osvik Ryste

Universitetslektor

Avdeling for helsefag, Norges teknisk-naturvitenskapelige universitet, Ålesund

Lindis Helberget

Universitetslektor

Avdeling for helsefag, Norges teknisk-naturvitenskapelige universitet, Ålesund

Eldre Munn Sykehjem Tannhelse Geriatri

\section{Hovedbudskap}

Eldre sykehjemsbeboere med mangelfull egenomsorg har behov for å få hjelp til munnstell. Studier viser at sykepleiere ikke prioriterer munnstell i det daglige stellet av beboerne. Noen årsaker til hvorfor denne oppgaven ikke blir prioritert, kan blant annet være sykepleieres holdninger, kompetanse og mangel på tid. Sykepleiere på sykehjem bør sette i gang fagutviklingsprosjekter innen tannhelse for beboere med egenomsorgssvikt. 
Flovik (1) hevder at utførelse av munnstell hos eldre på institusjon er en nedprioritert sykepleieoppgave. Noen pleiere kan oppfatte det å utføre munnstell som ubehagelig, noe som fører til at munnstellet neglisjeres. Eldrebølgen vil resultere i flere utfordringer for tannhelsen til pasienter på institusjon. Blant annet vil antallet tannproteser stadig bli redusert i og med at flere eldre beholder sine egne tenner eller har tannerstatninger $(2,3)$.

\section{Aldersforandringer i munnen}

Ved aldersforandringer endres tennenes struktur og utseende på grunn av for eksempel slitasje, skader og fargestoffer fra mat og drikke (4). De vanligste aldersforandringene som kan oppstå i munnhulen, er misfargede og sprø tenner, tilbaketrukket tannkjøtt, svekkede slimhinner, redusert spyttsekresjon og nedsatt muskelstyrke som kan gi dårlig tygge- og svelgfunksjon.

Disse endringene i kombinasjon med svekket immunforsvar, høyt sukkerforbruk, røyking og bruk av enkelte legemidler, som antibiotika eller glukokortikoider, kan $\varnothing$ ke infeksjonsfaren (4).

I løpet av noen måneder kan et økt bakterieantall i munnen $\varnothing$ delegge et velfungerende tannsett og danne grunnlag for livstruende tilstander som lungebetennelse, mage-tarminfeksjoner, hjerte- og karsykdommer og blodforgiftning (1). Infeksjoner og smerter i munnen kan forårsake problemer ved spising og drikking, noe som videre kan føre til underernæring og dehydrering hos eldre.

Dårlig munnhygiene kan også ha psykososiale aspekter, der blant annet kommunikasjon spiller en sentral rolle. Ved munntørrhet kan det være vanskelig å snakke, og dårlig ånde kan føre til at andre mennesker holder avstand overfor vedkommende (1).

\section{Sykepleierens negative holdninger}

Noen sykepleiere på sykehjem kan ha negative holdninger til det å utføre munnstell fordi det kan oppleves som frast $\varnothing$ tende. Disse sykepleierne overlater dermed slike oppgaver til andre i pleiegruppen. Årsaker til at tannpuss blir sett på som en ubehagelig pleieoppgave, kan være vond lukt eller slim fra pasientens munn $\left(2,3,5^{-9}\right)$. 
I en relasjon mellom en sykepleier og en pasient bør sykepleieren være bevisst på hvilke signaler som formidles gjennom verbal og nonverbal kommunikasjon, for eksempel ved at sykepleieren har et ansiktsuttrykk som formidler empati til tross for at munnen hos pasienten ikke er renslig. Det er viktig at sykepleierens handlinger og utsagn samsvarer for at pasienten skal kunne føle trygghet i situasjonen (1).

\section{Sykepleierens ansvar}

Sykepleiere på sykehjem har ulik ansvarsfølelse for munnstell.

Noen pleiere føler at munnstell er en del av den grunnleggende pleien og omsorgen, og at det er et felles ansvar. Andre mener at det er avdelingsledernes ansvar å gi klare instrukser om munnstell. Ledelsen kan være noe usikker på ansvarsområder innen tannhelse hos pasientene, men mener at munnstell er sykepleiernes hovedansvar $(6,7)$.

\section{$\equiv$ ¿Noen sykepleiere mener at det er avdelingsledernes ansvar å gi klare instrukser om munnstell.»}

Henderson (10) har definert hva som er sykepleierens selvstendige ansvarsområder, og hva som betraktes som delegerte ansvarsområder. Sykepleierne har et selvstendig ansvar på alle områder som handler om ivaretakelse av pasientens grunnleggende behov.

Ifølge «Yrkesetiske retningslinjer for sykepleiere» (11) er sykepleierens fundamentale plikt å fremme helse, forebygge sykdom, lindre lidelse og sikre en verdig $d \varnothing d$. Innenfor grunnleggende pleie anses det som uforsvarlig å unnlate å vise omsorg (12), noe som neglisjert munnhygiene kan være et eksempel på.

\section{Har sykepleiere nok kunnskap?}

Forskning viser at sykepleiere ofte har lite innsikt i og kunnskap om at dårlig tannhelse kan få alvorlige, helsemessige konsekvenser for eldre pasienter $(2,3,5-9,13)$. For lite kunnskap kan føre til at pleierne ikke oppdager sykdomstegn i munnen hos pasientene. Mangel på praktisk trening i hvordan munnstell skal utføres, kan også være en viktig årsak til at det blir lavt prioritert blant pleierne. Flertallet av sykepleierne mener de har tilstrekkelig kunnskap til å praktisere daglig munnhygiene $(2,8,13)$. 
Derimot er det kun et mindretall av pleierne som er fornøyd med resultatene av det daglige tannstellet som de utfører. Kunnskaps- og kompetansenivået hos sykepleierne om tannhelse viser at det kan være et misforhold mellom kompetansen sykepleierne har, og den praktiske gjennomføringen av munnstellet. Forskning viser likevel at sykepleierne har mindre kunnskap om årsakssammenhenger og behandling av gingivittproblemer - betennelse i tannkjøttet $(2,3,5-9,13)$.

\section{Stort behov for opplæring}

Det er generelt et stort behov for mer opplæring og økt kunnskap innen tannhelse. Flovik (1) hevder at det å ha flere repeterende opplæringsprogrammer kan føre til bedre munnhelse blant eldre sykehjemsbeboere. Sykepleierne $\varnothing$ nsker mer opplæring i selve utførelsen av munnstell fra tannhelsetjenesten. Til tross for at sykepleierne fikk opplæring og undervisning fra en tannpleier, var det bare noen eldre som fikk bedre tannhelse $(3,5,6,9)$.

\section{三 «Sykepleierne ønsker mer opplæring i selve utførelsen av munnstell fra tannhelsetjenesten.»}

De fleste sykepleiere har fått grunnleggende opplæring i oral hygiene i grunnutdanningen, men likevel viser studier at det ikke gir tilfredsstillende resultater. Det $b \varnothing r$ derfor innføres mer tannhelserelaterte læringsutbytter i den fremtidige sykepleierutdanningen $(1,2,7-9,13)$.

\section{Pasientens autonomi og integritet}

Flere studier viser at sykepleiere er generelt opptatt av pasientens autonomi og integritet $(2,3,5-9,13)$. Munnen kan oppfattes som et intimt og sensitivt område. De fleste pleiere mener at pasienter som er avhengige av hjelp, bør få beholde verdigheten sin ved at de selv kan delta aktivt i handlinger og bestemmelser angående deres egen pleie.

All pleie bør være basert på respekt og ivaretakelse av pasientens integritet, men i noen tilfeller kan autonomien til pasienten bli redusert. Det gjelder spesielt pasienter som er motvillige til å få utført munnstell $(2,3,5-9,13)$. 
Sykepleiere kan i enkelte utfordrende pasientsituasjoner oppleve en etisk konflikt mellom ivaretakelse av pasientens autonomi og en form for myk paternalisme (14). Noen sykepleiere kan da forsvare seg med at de ikke ønsker å frata de eldre verdigheten ved å overta ansvaret for munnstellet. I slike tilfeller bør pleierne forklare pasientene hvorfor de behøver assistanse (1).

\section{Bruk av tvang}

Flertallet av sykepleierne opplever av og til motstand fra noen pasienter. Over halvparten av disse pasientene har en demenslidelse (8). Sykepleierne lar ofte være å utføre munnstell på pasientene som motsetter seg hjelp, for ikke å skape unødig uro $(2,13)$. Mange pleiere opplever daglig etiske dilemmaer mellom frivillighet og tvang når pasienter ikke samarbeider under munnstellet.

\section{三 «Sykepleierne lar ofte være å utføre munnstell på pasientene som motsetter seg hjelp, for ikke å skape unødig uro.»}

Noen sykepleiere er usikre på om tvang er riktig (2, 13). Ved tvang kan pleierne få dårlig samvittighet, men følelsen kompenseres av den positive effekten for pasienten (3). Kun et mindretall av sykepleierne vurderer å fatte tvangsvedtak for å kunne utføre nødvendig munnstell. Mange sykehjem har som første mål å oppnå en god utførelse av pleie basert på tillitsforhold mellom sykepleiere og pasienter, før et eventuelt tvangsvedtak fattes (8).

\section{Et ledelsesansvar?}

Mange pleiere hevder at andre sykepleieoppgaver ofte får høyere prioritet enn munnstell på grunn av tidsn ød og motstand fra pasienten (2, 3, 5-9). En studie (5) viste at sykepleiere hadde ulike meninger om hva som var årsaker til tidspress, slik som redusert bemanning, $\varnothing \mathrm{kt}$ arbeidsbelastning eller nedprioritering fra ledelsen. Selv om en del sykepleiere mener at de har tilstrekkelig tid til å utføre munnstell, viser studier likevel at tannhelsen hos sykehjemsbeboere er for dårlig $(2,5,13)$. 
Det er generelt mangel på retningslinjer om munnstell til eldre sykehjemsbeboere $(2,3,5-9)$. Selv om klare retningslinjer og anbefalinger var implementert, var det kun halvparten av pleierne som fulgte dem (7). Adekvate retningslinjer og munnstellprosedyrer kan være nyttige for sykepleiere slik at de vet hva de må observere og utføre for å forebygge infeksjoner i pasientens munnhule (1).

\section{Konkrete tiltak}

Praktiske retningslinjer kan utarbeides sammen med en tannpleier. Manglende rutiner kan skyldes svak faglig ledelse og oppfølging samt kommunikasjonssvikt pleierne imellom (9). For å kunne vedlikeholde nye rutiner er det viktig med kontinuerlig oppfølging fra ledelsen, noe som kan signalisere at tannstell oppfattes som en viktig pleieoppgave.

Munnstell blir ofte ikke diskutert når pleieplaner utarbeides, og dokumentasjon blir nedprioritert $(2,3,6,9)$. Gode rutiner for jevnlig observasjon og dokumentasjon av tilstanden i munnhulen vil kunne bidra til bevisstgjøring om at munnstell er en grunnleggende del av stellet (1), og vil også bidra til bedre pasientsikkerhet (15).

\section{$\equiv$ ¿Munnstell blir ofte ikke diskutert når pleieplaner utarbeides, og dokumentasjon blir nedprioritert.»}

Flere studier viser at det er behov for bedre kommunikasjon og samarbeid mellom kolleger og mellom ledelse og pleiere $(2,3,5-9)$. Videre kom det frem i studiene at det kan være lite struktur på kontakten mellom sykehjem og tannhelsetjenesten, der pleierne ikke alltid synes det er lett å gjennomføre instruksjoner fra tannhelsepersonellet i praksis. Det er også et $\varnothing$ nske at sykepleierne kan assistere hverandre i utfordrende pasientsituasjoner (2, 6-8).

\section{Oppsummering og anbefaling for praksis}

Sykepleiernes daglige utfordringer innen munnstell hos eldre er sammensatte. En av de største utfordringene er holdninger som skepsis og avsky, motstand fra pasientene og tidsnød. Flere sykepleiere synes det er vanskelig å finne en balanse mellom å ivareta pasientens autonomi og bruke paternalisme.

Det er viktig med en bevisstgjøring av holdninger, kompetanseheving blant sykepleiere og innføring av gode rutiner og retningslinjer. Sykepleiere på sykehjem bør sette i gang fagutviklingsprosjekter innen tannhelse. 


\section{Referanser}

1. Flovik AM. Munnstell. Godt munnstell nødvendig og helsebringende. Oslo: Akribe; 2005.

2. Forsell M, Sjögren P, Kullberg E, Johansson O, Wedel P, Herbst B, et al. Attitudes and perceptions towards oral hygiene tasks among geriatric nursing home staff. Int J Dent Hyg. 2011;9(3):199-203. DOI: 10.1111/j.1601-5037.2010.00477.x

3. Wårdh I, Hallberg LRM, Berggren U, Andersson L, Sörensen S. Oral health care - a low priority in nursing: in depth interviews with nursing staff. Scand J Caring Sci. 2000;14(2):137-42.

4. Samson H, Strand GH. Den gamle pasientens helseproblemer. I: Kirkevold M, Brodtkorb K, Ranhoff AH, red. Geriatrisk sykepleie - God omsorg til den gamle pasienten. Oslo: Gyldendal Norsk Forlag; 2014. s. 284-511.

5. De Visschere L, De Baat C, De Meyer L, Van der Putten GJ, Peeters B, Vanobbergen J. The integration of oral health care into day-to-day care in nursing homes: a qualitative study. Gerodontology. 2015;32(2):115-22. DOI:

$\underline{10.1111 / \text { ger.12062 }}$

6. Lindqvist L, Seleskog B, Wårdh I, Bulzinglöwen I. Oral care perspectives of professionals in nursing homes for the elderly. Int J Dent Hyg. 2013;11(4):298-305. DOI:

$\underline{10.1111 / \text { idh.12016 }}$

7. Sonde L, Emami A, Kiljunen H, Nordenram G. Care providers' perceptions of the importance of oral care and its performance within everyday caregiving for nursing home residents with dementia. Scand J Caring Sci. 2011;25(1):92-9.

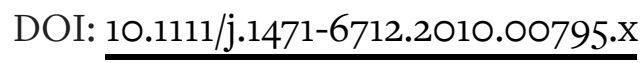

8. Willumsen T, Karlsen L, Naess R, Bjørntvedt S. Are the barriers to good oral hygiene in nursing homes within the nurses or the patients? Gerodontology. 2012;29(2):748-55. DOI: $10.1111 / \mathrm{j} .1741-2358.2011 .00554 \cdot \mathrm{X}$

9. Wårdh I, Jonsson M, Wikström M. Attitudes to and knowledge about oral health care among nursing home personnel - an area in need of improvement. Gerodontology. 2012;29(2):787-92. DOI: 10.1111/j.1741-2358.2011.00562.x 
10. Mathisen J. Hva er sykepleie? Virginia Hendersons svar.

I: Holter IM, Mekki TE, red. Grunnleggende kunnskap i

klinisk sykepleie. Sykepleieboken 1. Oslo: Akribe; 2011. s. 14968.

11. Norsk Sykepleierforbund. Yrkesetiske retningslinjer for sykepleiere. Oslo; 2011. Tilgjengelig fra:

https:/www.nsf.no/Content/2182990/seefile (nedlastet

24.09.2018).

12. Lov 2. juli $1999 \mathrm{nr} .64$ om helsepersonell

(helsepersonelloven). Tilgjengelig fra:

https://lovdata.no/dokument/NL/lov/1999-07-02-

64\#KAPITTEL_2 (nedlastet 24.09.2018).

13. Kullberg E, Sjögren P, Forsell M, Hoogstraate J, Herbst B, Johansson O. Dental hygiene education for nursing staff in a nursing home for older people. J Adv Nurs. 2010;66(6):12739. DOI: $\underline{10.1111 / \mathrm{j} .1365-2648.2010 .05298 . \mathrm{x}}$

14. Brinchmann BS. De fire prinsippers etikk - velgjørenhet, ikke-skade, autonomi og rettferdighet. I: Brinchmann BS, red. Etikk i sykepleien. Oslo: Gyldendal Norsk Forlag; 2012. s. 8196.

15. Vabo G. Dokumentasjon i sykepleie. Oslo: Cappelen Damm Akademisk; 2014.

\section{三 $\ll$ For lite kunnskap kan føre til at pleierne ikke oppdager sykdomstegn i munnen hos pasientene.»}

